\title{
Herpesvirus cyprini: Biological and Oncogenic Properties
}

\author{
Tokuo Sano, H. Fukuda, and M. Furukawa \\ Laboratory of Fish-Pathology, Tokyo University of Fisheries
}

\begin{abstract}
In the present paper, we described the general biological properties and the oncogenicity of Herpesvirus cyprini or cyprinid herpesvirus 1 (CHV) (SANo, et al., 1984) which were isolated from nine papilloma tissues developed on the skin or the caudal fin of Japanese carp.

The virus size were as follows; envelope diameter $190.4 \pm 27.2 \mathrm{~nm}$, projection length $20.5 \pm 4.4 \mathrm{~nm}$, capsid diameter $113.4 \pm 8.6 \mathrm{~nm}$. This herpesvirus showed good significant growth on FHM and MCT The virus titer on FHM cells reached more than $10^{5.5} \mathrm{TCID}_{50} / \mathrm{m} /$ at $20 \mathrm{C}$ incubation temperature for 14 days. Syncytium formation was not found in these cell lines. Both FHM and EPC cells infected with this virus possessed intranuclear inclusion, Cowdry type A. It occupied a relatively large area revealing rather irregular shape. The virus titer reduction of over $10^{3} \mathrm{TCID}_{50} / \mathrm{m} /$ occurred before and after treatment with

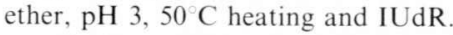

A cluster of the virus particles was found inside and outside inclusion body in FHM cells infected with the virus. Virus particles were more numerous in the karyoplasm undergoing karyorrhexis Budding immature virus particle from the nuclear membrane, as well as released virions in intracellular space, were observed.

Oncogenicity trial which we performed using common carp revealed grossly tumors on three fish out of ten. These tumor formations occurred more than five months after inoculation at $15.2 \mathrm{C}$ of rearing temperature. The tumor cells induced in Asagi carp inoculated with the virus showed many virus particles in the karyoplasm and the cytoplasm.

The experimentally induced tumors on common carp and spontaneously-developed tumors on colored carp possessed the property to be desquamated at the natural condition.
\end{abstract}

\section{Introduction}

In Europe the papillomatous condition known as carp pox has been recognized since the Middle Ages (WoLf, 1983). The etiology was uncertain up to this time, but it is worthy of special mention that SCHUBERT (1964) provided the first viral evidence by means of electron micrographs. Although Sonstegard and Sonstegard (1978) tried to isolate any virus from the papilloma developed on American carp on FHM and other fish cell lines, they were not successful. However, they suggested that the papilloma could have been caused by virus since similar tumor appeared on the experimental fish which was kept together with the tumor bearing fish. Thus far, no one could isolate any viral agents directly from the tumor tissue, or from any other part of the host fish.

As reported in our previous paper (SANO et al., 1984), we succeeded in isolating a herpesvirus from the papilloma tissue (Figs. 1 and 2) developed on the skin and the caudal fin of fancy carp of the race called Asagi which had been raised in a commercial ornamental carp pond at Niigata Prefecture, in October of 1981. We designated this virus Herpesvirus cyprini. This paper describes more comprehensively the biological and oncogenic properties

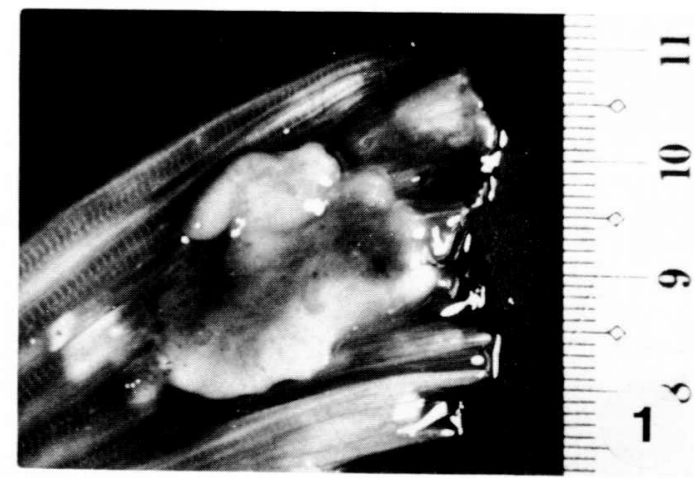

Fig. 1. Gross appearance of the papilloma developed spontaneously on carp. 


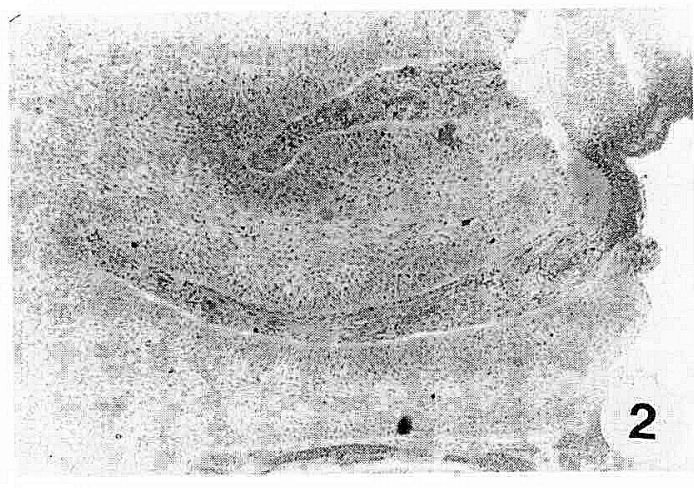

Fig. 2. Histological findings of the papilloma developed spontaneously. The tumor tissue is organized with well differentiated cells and epidermal peg interdigitats with papilla of dermal connective tissue which contains also vessel and others.

of the Herpesvirus cyprini.

\section{Materials and Methods}

Virus susceptible fish cell lines were investigated including 13 cell lines: EPC, MCT, FHM, CE-1 (Asagi Carp Embryo), RTG-2, BF-2, BB, SF (Sturgeon Fin), $\mathrm{CHH}_{-1}$ (Chum salmon Heart), TNK (Tilapia nilotica Kidney), SSE-5, EO (Eel Ovary), EK (Eel Kidney).

The virus was titrated on these cells incubated for 14 days at $20^{\circ} \mathrm{C}$. Since the virus titer of Herpesvirus cyprini in FHM cells was higher than in EPC cells, we routinely used FHM cells for the subculture, and CE-1, MCT cells as well as FHM cells for a study on the viral antigen detection in cell inoculated with the herpesvirus. These cell lines were inoculated and incubated at $20^{\circ} \mathrm{C}$. For the observation of the inclusion body, inoculated cells were stained with May Grünwald-Giemsa.

For infectivity trial, 1.5-year-old common carp, which were raised in Yoshida Training Center, Tokyo University of Fisheries, weighing 220 to $480 \mathrm{~g}$, and average of $314 \mathrm{~g}$, were inoculated intraperitoneally. The intraperitoneal dose per fish was $0.3-0.5 \mathrm{~m} /$ of virus $10^{5.4} \mathrm{TCID}_{50} / \mathrm{m} /$, which was harvested in FHM cells. The same volume of Hanks' BSS was inoculated into each fish of different fish group. These groups were CHV harvested in FHM cells and control. Each group consisted of 10 fish. After injection, all fish of these groups were raised separately in each trough with fluctuating temperatures of 13.0 to $16.5^{\circ} \mathrm{C}$, an average of $15.2^{\circ} \mathrm{C}$ throughout the experimental period from July of 1983 to July of 1984 .

A papilloma bearing Asagi carp was kept in an aquarium in our wet laboratory for long term observation of the tumor condition, from November of 1983 to June of 1984.

Prior to negative staining of the virus, the virus was clonized, grown in FHM cells and then the cultured fluid was concentrated by adding $6.5 \%$ PEG- 6000 and $\mathrm{NaCl}$ to the final concentration of $0.4 \mathrm{M}$ and stirring for $120 \mathrm{~min}$ at $4^{\circ} \mathrm{C}$. The mixture was centrifuged at $2,000 \times g$ for $30 \mathrm{~min}$ at $4^{\circ} \mathrm{C}$. The sediment was resuspended in Hepes buffered MEM-2 (pH 7.4) and centrifuged at $18,500 \times g$ for $30 \mathrm{~min}$. The sediment was then resuspended in $0.005 \mathrm{M}$ Tris ( $\mathrm{pH}$ 7.4) containing $0.1 \%$ bovine serum albumin to $1 / 200$ volume of the original virus solution. The virus was concentrated from $10^{4.8}$ to $10^{7.1}$ $\mathrm{TCID}_{50} / \mathrm{ml}$ on the final procedure. The virus concentrated was negatively stained with $1 \%$ uranyl acetate or $2 \%$ PTA (pH 7.0) on copper grids. For ultrathin section of papilloma, the tumor tissue developed on the skin and the caudal fin of Asagi carp was prefixed for $50 \mathrm{~min}$ with cold $2.5 \%$ glutaraldehyde in $0.1 \mathrm{~m}$ phosphate buffer. The prefixed specimens were rinsed ten times for $20 \mathrm{~min}$, each time with cold $7.5 \%$ sucrose in $0.1 \mathrm{M}$ phosphate buffer solution and finally were kept for $12 \mathrm{~h}$ at $4^{\circ} \mathrm{C}$. Subsequently the specimens were postfixed for one hour with cold $1 \%$ osmium tetroxide in PBS $(-)$ after the sucrose solution was decanted. These specimens were dehydrated in alcohol, embedded in epoxy resin, sectioned and stained with $1 \%$ uranyl acetate for $30 \mathrm{~min}$ and with lead acetate (Millonig B method) for $15 \mathrm{~min}$ on copper grids.

IUdR inhibition test was carried out as follows: MEM-2 Hepes containing IUdR $10^{-3.7}$ M, MEM-2 Hepes containing IUdR $10^{-3.7} \mathrm{M}$ plus $10^{-3}$ thymidine, and MEM-2 Hepes were provided. The virus solutions were diluted in serial 10 -fold steps from $10^{-1}$ to $10^{-5}$ with each solution, and $0.05 \mathrm{~m} /$ of each mixture was inoculated into each well of eight wells provided for one step dilution which were seeded with $0.1 \mathrm{ml}$ of FHM cells. Mock controls were prepared in the same way. These wells were incubated for 14 days at $20^{\circ} \mathrm{C}$. NeVTA as the positive control and IPNV as the negative control, were prepared in the same procedure mentioned above. 
They were inoculated into CHSE-214 cells and incubated 14 days at $15^{\circ} \mathrm{C}$.

Acid ( $\mathrm{pH} 3.0$ ) susceptibility test was carried out as follows: $0.2 \mathrm{~m} /$ of the virus was added into $1.8 \mathrm{~m} /$ of MEM (pH 3.0) without $\mathrm{NaHCO}_{3}$ and MEM adjusted to $\mathrm{pH} 7.2$ by adding $0.01 \mathrm{M}$ Tris buffer solution and reacted for three hours at $4^{\circ} \mathrm{C}$ agitating strongly. And then, after adjusted MEM ( $\mathrm{pH} 3.0$ ) without $\mathrm{NaHCO}_{3}$ to $\mathrm{pH} 7.2$ by adding $0.1 \mathrm{M}$ Tris buffer solution, both the mixture were diluted 10 fold, from $10^{0}$ to $10^{-4}$, inoculated into FHM cells which was seeded in eight wells for each dilution, incubated for 14 days at $20^{\circ} \mathrm{C}$ and titrated.

Ether susceptibility test was performed as follows: $0.12 \mathrm{~m} /$ of ethyl ether was added into $0.5 \mathrm{~m} /$ of the virus and shooked vigorously for $18 \mathrm{~h}$ at $4 \mathrm{C}$. After evaporated the ether in the mixture by bubbling with $\mathrm{N}_{2}$-gas, the reacted virus was inoculated into FHM cells, incubated for 14 days at $20^{\circ} \mathrm{C}$ and titrated in the same way as in acid susceptibility test.

Heat stability test was carried out as follows: $0.5 \mathrm{~m} /$ of the virus heated at $50^{\circ} \mathrm{C}$ for $30 \mathrm{~min}$ was inoculated into FHM cells, incubated for 14 days at $20^{\circ} \mathrm{C}$ and titrated. The control virus was exposed at room temperature.

\section{Results}

CPE, in cell lines inoculated with the virus diluted more than $10^{-1}$ dilution, were limited to only FHM, EPC, MCT and CE-1 (Table 1). The virus titer in each cell line was as follows: $10^{5.8}$ $\mathrm{TCID}_{50} / \mathrm{m} /$ in FHM, $10^{5.8}$ in MCT, $10^{3.8}$ in CE- 1 and $10^{2.8}$ in EPC. There were characteristic differences in appearance of CPE among these four cell lines. In FHM cells, the infected cells revealed primarily vacuolation, in addition to roundness and also slight pyknosis in the focal area on the cell sheet 5 days after inoculation. Subsequently, CPE expanded from focal area to adjacent cells and the cellular desquamation at focal area occurred slowly. Cellular recovery at such area also was occasionally observed. About $30-40 \%$ cells still remained 2weeks after inoculation. We recognized this condition as CPE completion in FHM cells. In MCT cells, CPE began to appear obscurely, but evenly over all cell sheet 5 days after inoculation and focal CPE was not remarkable. This was the contrasting difference between FHM and MCT cells. In MCT cells, the affected cells tended to lead to cellular
Table 1. CHV susceptive fish cell lines and effect of incubation temperature on cytopathic effect

\begin{tabular}{llccc}
\hline \hline & & \multicolumn{3}{c}{ Temperature $(\mathrm{C})$} \\
Cell line & 10 & 15 & 20 & 25 \\
\hline FHM & - & ++ & +++ & - \\
EPC & - & + & + & - \\
MCT & - & + & +++ & - \\
CE-1 & - & + & ++ & - \\
RTG-2 & - & - & - & - \\
CHH-1 & - & - & - & - \\
SSE-5 & - & - & - & - \\
BF-2 & - & - & - & - \\
BB & - & - & - & - \\
EO & - & - & - & - \\
EK & - & - & - & - \\
TNK & - & - & - & - \\
SF & - & - & - \\
\hline
\end{tabular}

- , Negative; + , weakly positive $\left(10^{2.8} \mathrm{TCID}_{50} / \mathrm{m} /\right)$; ++ , positive $\left(10^{3.8} \mathrm{TCID}_{50} / \mathrm{m} /\right) ;+++$, strongly positive $\left(10^{5.8} \mathrm{TCID}_{50} / \mathrm{m} /\right)$.

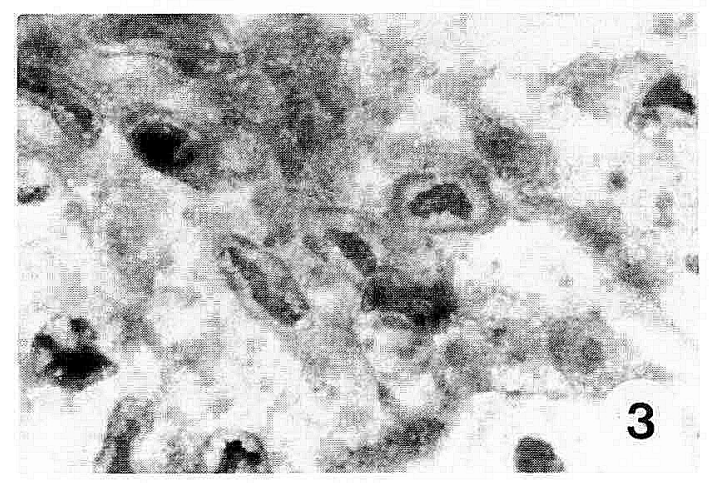

Fig. 3. Intranuclear inclusion bodies formed in FHM cells infected with Herpesvirus cyprini, which is interpreted as Cowdry type A. Stained with May Grünwald-Giemsa.

collapse after they became swollen or became round without cellular desquamation. In both EPC and CE-2 (Kohaku Carp Embryo) cells, CPE is less remarkable than FHM and $\mathrm{MCT}$. In comparison with the control cell, the infected EPC and CE-2 cells did exhibit some cellular roundness and desquamation. CPE in both cell lines began to appear around 10 days after inoculation. However, immunofluorescent antibody technique showed that 5 th day after inoculation the viral antigen existed only in the karyoplasm of CE-2 cells inoculat- 
ed with $H$. cyprini and incubated at $20^{\circ} \mathrm{C}$. Syncytium formation in the present study also was not found in FHM and EPC cells. However, FHM cells which were infected with this herpesvirus showed advanced CPE, and possessed intranuclear inclusion which were interpreted as Cowdry type A. In many cases, it was surrounded by a halo (the space between the inclusion and the nuclear membrane often appeared as non-stained area with May-Grünwald Giemsa) and occupied a relatively large area in the karyoplasm, revealing somewhat irregular shape (Fig. 3).

The virus titer was $10^{5.8} \mathrm{TCID}_{50} / \mathrm{m} /$ in FHM and has been remained at that level in FHM cells thus far.

As shown in Table 2, the virus titer reduction of significantly large difference over $10^{3} \mathrm{TCID}_{50} / \mathrm{m} /$ occurred regardless of any treatment used.

This herpesvirus has possessed comparatively long filamentous projections, and were thicker at top. It is different from spike-like NeVTA (SANO, 1976) found on the surface of the envelope. The envelope of $H$. cyprini showed membrane-like structure (Fig. 4). The tegument of this virus was considerably less than the herpesvirus YTV (SANO et al., 1983) isolated from the basal cell epithelioma tissue on Yamame, Oncorhynchus masou and

Table 2. Titer reduction of CHV after treatment with ether, pH 3, heat and IUdR

\begin{tabular}{ccc}
\hline \multirow{2}{*}{ Treatment } & \multicolumn{2}{c}{ Virus titer in $\log \mathrm{TCID}_{50} / \mathrm{m} /$} \\
\cline { 2 - 3 } & Before treatment & Reduction \\
\hline Ether & 3.9 & $>3.1$ \\
pH 3 & 4.5 & $>3.8$ \\
Heat & 3.8 & $>3.0$ \\
IUdR & 5.1 & $>4.3$ \\
\hline
\end{tabular}

Table 3. Dimension of CHV virion

\begin{tabular}{cccc}
\hline \hline Portion & $\begin{array}{c}\text { Range } \\
(\mathrm{nm})\end{array}$ & $\begin{array}{c}\text { Average } \\
(\mathrm{nm})\end{array}$ \\
\hline $\begin{array}{c}\text { Envelope in } \\
\text { diameter } \\
\text { Projection in } \\
\text { length } \\
\begin{array}{c}\text { Capsid in } \\
\text { diameter }\end{array}\end{array}$ & $153.5-239.9$ & $190.4 \pm 27.2 \quad(n=42)$ \\
\hline
\end{tabular}

possessed low electron-density. Dimension in each portion of this virus as shown in Table 3 .

The relative comparison of the envelope between H. cyprini and NeVTA showed that the size of former's envelope was significantly smaller than the NeVTA's envelope. $H$. cyprini profile was irregular round shape and seemed to be similar to HSV.

Many virus particles were observed in thin sectioned tumor cells of the papilloma developed on Asagi carp inoculated with $H$. cyprini. Particularly, the virus particles were more in the cytoplasm showing diverse virus profiles (Fig. 5). In the nucleus, also the diverse viral particles and several virogenic stages were observed. The tumor cells in which the virus particles were found, generally revealed the reduction in staining of mitochondria, endoplasmic reticulum and other organella or dis-

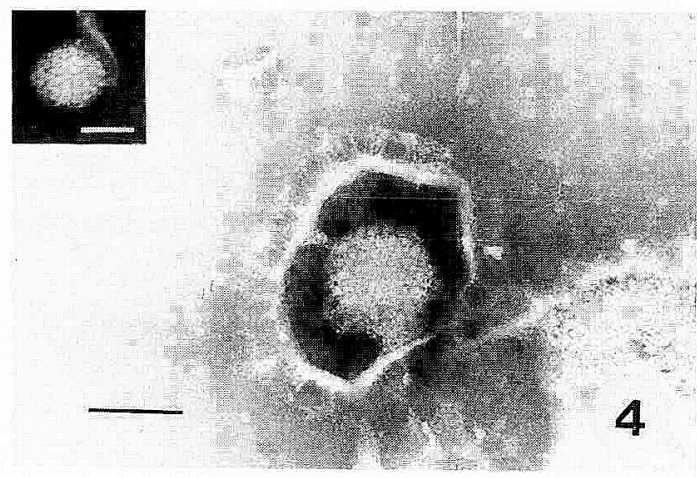

Fig. 4. The profile of $H$. cyprini. Note comparatively long projections which are filamentous with thicker at top on the surface of the envelope (bar $=100 \mathrm{~nm})$

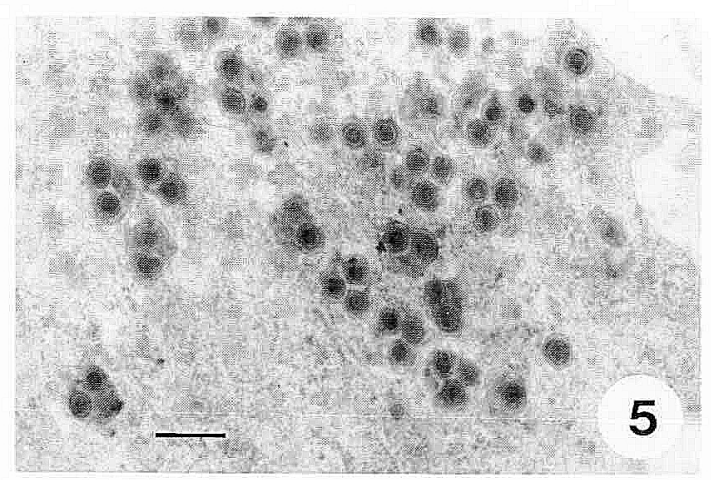

Fig. 5. Many herpesvirus particles found in the cytoplasm of thin sectioned tumor cell of the papilloma developed on the skin of the Asagi carp inoculated with the $H$. cyprini (bar $=300 \mathrm{~nm}$ ). 


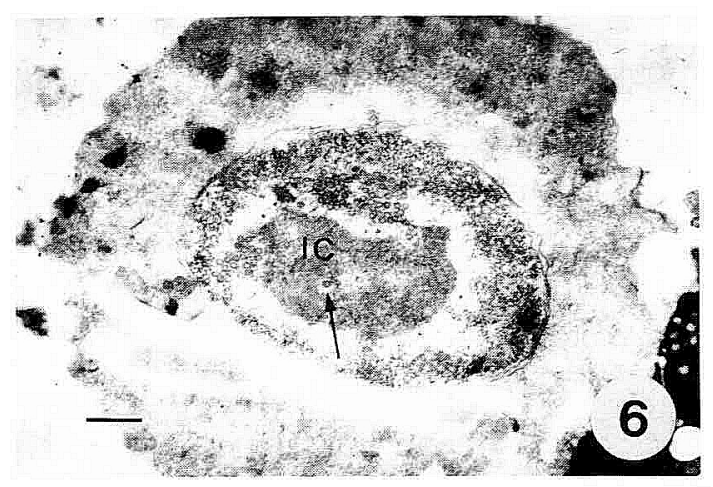

Fig. 6. Appearance of many viral particles, reduction in staining of mitochondria, endoplasmic reticulum and etc., disappearance of such organellae. The intranuclear inclusion can be found in such tumor cell. Some virus particles occluded (arrow) in the intranuclear inclusion and a cluster of the virus particles released outside the inclusion. IC indicates inclusion ( $\mathrm{bar}=1 \mu$ ).

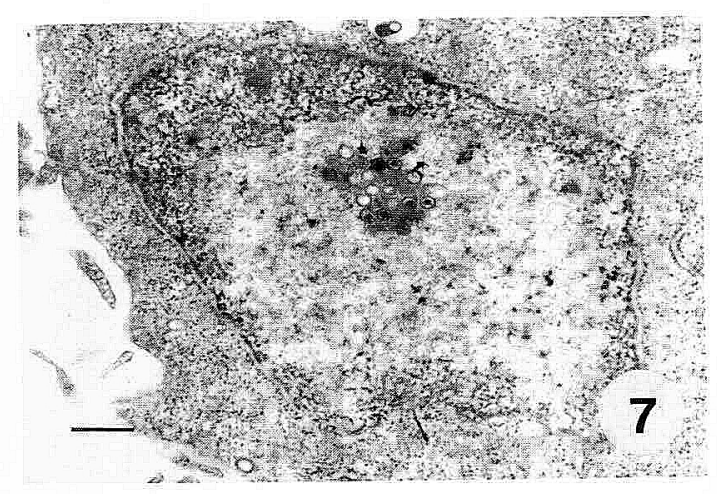

Fig. 7. Virus particles occluded in an intranuclear inclusion in FHM cell infected with $H$. cyprini (bar $=500 \mathrm{~nm})$.

appearance of such organella. Noticeable reduction of staining was observed in the inner area of the nucleus of the cell in which constructing viral particles were frequently found (Fig. 6). Intranuclear inclusion was also recognized in the tumor cells mentioned above. It showed rather irregular shape with low electron-density and occluded a few virus particles. A cluster of the virus particles was found simultaneously outside the inclusion (Fig. 6). Figure 7 also shows the virus occlusion in an intranuclear inclusion appeared in FHM cells infected with $H$ cyprini. In thinsectioned FHM cells inoculated with this virus, the virus particles were generally found less in the

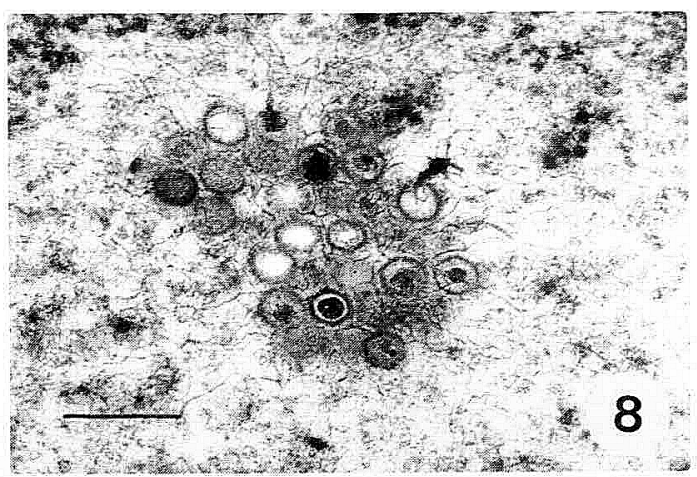

Fig. 8. Virus particles which are touched on or penetrated with filament-like materials derived from the area with high electron-density. It seems that the nucleocapsid is going to be equipped with such materials (bar $=300 \mathrm{~nm}$ ).

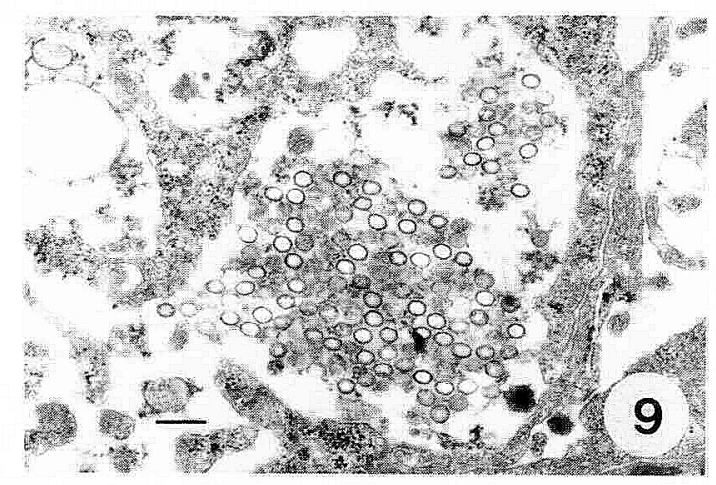

Fig. 9. Virus particles appeared numerously in the karyoplasm undergoing karyorrhexis in FHM cells infected with $H$. cyprini (bar $=300 \mathrm{~nm}$ ).

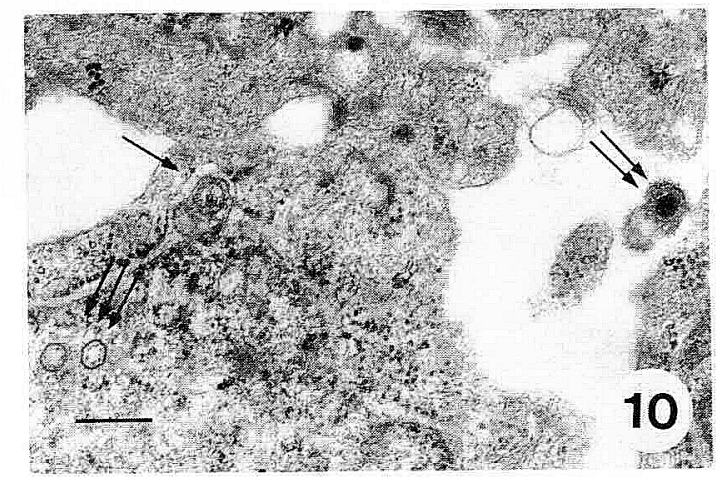

Fig. 10. Budding virus particles from the nuclear membrane and released virions into intracellular space. An arrow indicates budding. Two arrows indicate released. Three arrows indicate capsid (bar $=300 \mathrm{~nm}$ ). 
cytoplasm while they existed numerously in the karyoplasm. Diverse figures we observed in the karyoplasm may help to understand the virogenic process. Namely, many different viral particles assembled to a certain area of the karyoplasm showed low electron-density and the area surrounding those particles showed high density. We found out that

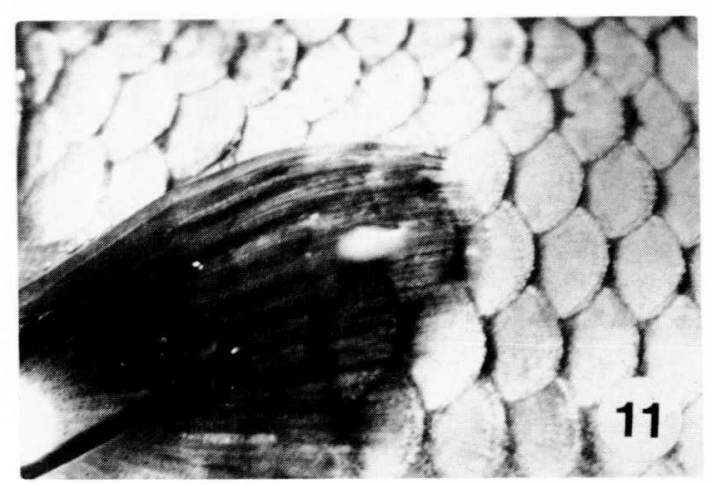

Fig. 11. A tumor developed on the right pectoral fin of the experimental common carp inoculated with H. cyprini. It was found six months after inoculation.
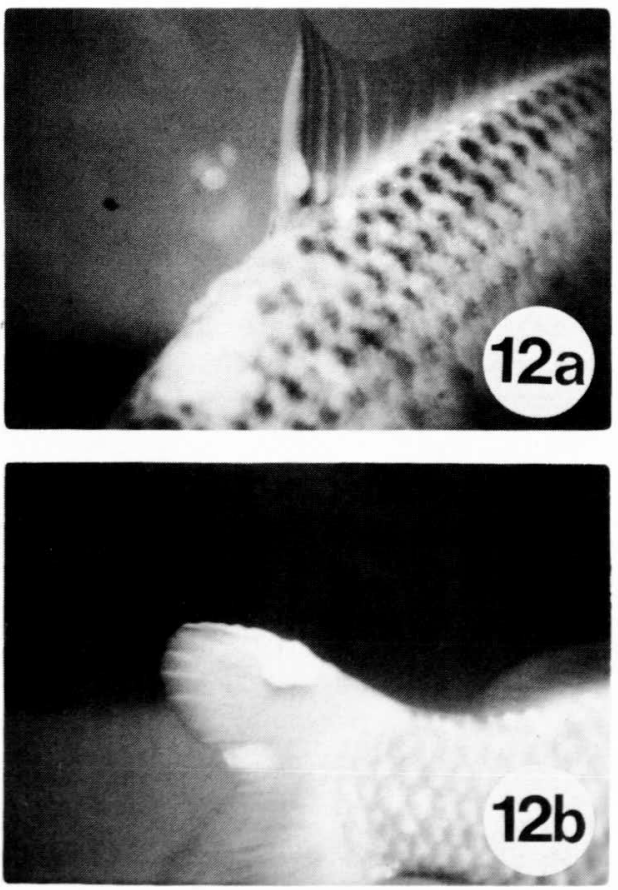

Fig. 12. Two tumors developed spontaneously on the dorsal skin (a) and the caudal fin (b) of Asagi carp. Photographed in March, 1984 some particles were surrounded, touched by or penetrated with filament-like materials (Fig. 8). These filament-like materials having diverse length and radial arrangement in high density, were found throughout the karyoplasm (Fig. 8). Virus particles were more numerous in the karyoplasm undergoing karyorrhexis (Fig. 9). Budding virus particles from the nuclear membrane, were observed (Fig. 10).

In Table 4, the results of the oncogenicity trial are shown. No mortality was recorded since we set up the experiment and through April 30, 1984, either in the experimental group and the control group. However, the experimental group which was inoculated with CHV harvested in FHM, disclosed

Table 4. Incidence of the papilloma bearing experimental fish found six months after inoculation by intraperitoneal injection into common carp with $\mathrm{CHV}$

\begin{tabular}{cc}
\hline Control & CHV harvested in FHM \\
\hline $0 / 10$ & $3 / 10$ \\
\hline
\end{tabular}
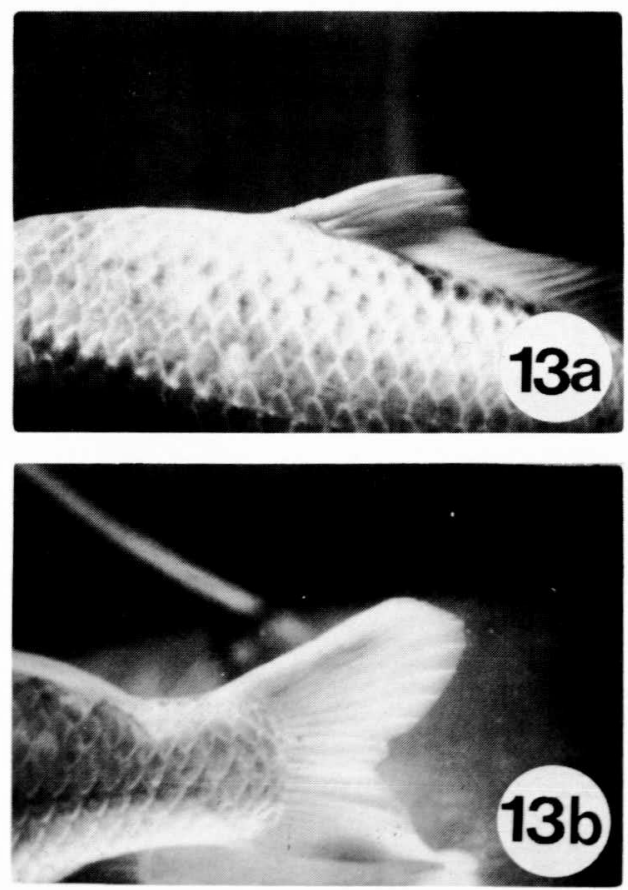

Fig. 13. Entirely spontaneously desquamated two tumors on the same fish as shown in Fig. 12. Photographed June 15, 1984. 
the tumor formation in three out of ten fish.

We found a tumor formation on the right pectoral fin of the experimental carp which had been inoculated with $H$. cyprini on January 31, 1984 (Fig. 11). It took more than five months after inoculation to develope the visible tumor at average water temperature of $15.2^{\circ} \mathrm{C}$. These tumors desquamated spontaneously before tumor tissue had developed enough for sample to be collected for both histological and virological studies.

Our observation indicated that all papilloma which developed naturally on the caudal fin and the dorsal skin of one Asagi carp, desquamated spontaneously. We had traced the tumor condition of one Asagi which was kept in our aquarium at average water temperature of $16.4^{\circ} \mathrm{C}$ (November, 1983), $11^{\circ} \mathrm{C}$ (January to March, 1984) and $22.0^{\circ} \mathrm{C}$ (June, 1984) (Figs. 12 and 13). The desquamated lesions were smooth and not hemorrhagic.

\section{Discussion}

We succeeded in isolating Herpesvirus cyprini or cyprinid herpesvirus 1 from the papilloma tissue on the caudal fin and the skin of nine carp, which included one tumor tissue desquamated from the skin into water, over the two years period from October, 1981 to November, 1983 in Japan.

We found some similarities between the virus profile in ultrathin section of $H$. cyprini and that which SCHUBERT $(1964,1966)$ showed for carp pox virus in ultrathin sections. However, neither SCHubERT nor SonSTEGARd and SonSTEGARD (1978) were able to isolate the virus of carp pox.

Of course, $H$. cyprini was entirely different from CCV (Wolf and Darlington, 1971), NeVTA (SANO, 1976), H. salmonis (wOLF et al., 1978), OMV (Kimura et al., 1981), YTV (SANo et al., 1983) and H. vitreum (KELLY et al., 1983) which have already been isolated.

In the present paper, we described the general biological properties of $H$. cyprini and its oncogenicity. The results obtained from the oncogenicity trial, which we have performed using common carp in this study, verified that this herpesvirus experimentally reproduced naturally occurring tumor, these supporting the results in our previous study (SANo et al., 1984). Consequently, we came to the conclusion that Herpesirus cyprini may be the causative agent of carp papilloma.
Although the term carp pox has been used for many years, it is a misnomer because the lesions are not really pox. Similarly, epithelioma papulosum is not a proper designation because neither the spontaneously occurring tumor nor the experimentally induced tumor (SANO et al., 1985) possess the histological characteristics of the basal cell epithelioma of $O$. masou discribed by SANO et al. (1983). Since the lesions possess characteristics of papilloma, we propose that the term papillosum cyprini be used hereafter instead of carp pox or epithelioma papulosum.

Future studies are anticipated on whether this herpesvirus is pathogenic to the other cyprinids and to the juvenile fishes. Past studies on OMV and YTV had revealed the high pathogenicity of the viruses to juvenile of some salmonids. Studies on the molecular characterization of Herpesvirus cyprini is also planned.

\section{Acknowledgements}

The authors wish to acknowledge Dr. W. T. Yasutake, Research Histologist, National Fishery Research Center, Seattle, Washington, USA, for his review of this manuscript. The authors are grateful to Dr. J. Harshbarger, Director, Registry of Tumors in Lower Animals, National Museum Smithsonian Institution, Washington, D. C. for his kindly arranging our joint histological examination.

\section{References}

Kelly, R. K., O. Nielsen, S. C. Mitchell, and T. YAMAMOTO (1983): Characterization of Herpesvirus isolated from Hyperplastic epidermal tissue of walleye, Stizostedion vitreum vitreum (MrTchiLl). J. Fish Diseases, 6, 249-260.

Kimura, T., M. Yoshimizu, M. TanaKa, and H. SANnohe (1981): Studies on a New Virus (OMV) from Oncorhynchus masou-1. Characteristics and Pathogenicity. Fish Pathol., 15(3/4), 143-147.

SANO, T. (1976): Viral diseases of cultured fishes in Japan. Fish Pathol., 10(2), 221-226.

Sano, T., H. Fukuda, N. OKamoto, and F. Kaneko (1983): Yamame tumor virus: Lethality and oncogenicity. Bull. Japanese Soc. Sci. Fish., 49(8), 1159-1163.

Sano, T., H. Fukuda, M. Furukawa, H. Hosoya, and Y. MoriYa (1985): A Herpesvirus isolated from Carp Papilloma in Japan. In: Fish and Shellfish Pathology (ed. by A. E. Ellis): Academic Press, San Diego, 307-311. 
SCHUBERT, G. (1964): Elektronenmikroskopische Untersuchungen zur Pockenkrankheit des Karpfens. $Z$. Naturforsch, 19, 676-682.

SCHUBERT, G. (1966): The infective agent in carp pox. Bull. Off. Int. Epiz., 65(7-8), 1011-1022.

Sonstegard, R. A. and K. S. Sonstegard (1978): Herpesvirus associated epidermal hyperplasia in fish (carp). In: Proceedings of the International Symposium on Oncogenesis and Herpesviruses III (G. De-The, W. Henle, and F. Rapp, eds.), 863-868, International Agency for Research on Cancer, Scientific Publication No. 24, Lyon, France.
Wolf, K. and R. W. Darlington (1971): Channel catfish virus: a new herpesvirus of ictalurid fish. J. Virol., 8, 525-533.

Wolf, K., R. W. Darlington, W. G. Taylor, M. C. Quimby, and T. NAGABAYASHI (1978): Herpesvirus salmonis: Characterization of a new pathogen of rainbow trout. J. Virol., 27(3), 659-666.

WOLF, K. (1983): Biology and properties of fish and reptilian herpesviruses. In: The Herpesviruses, Volume 2 (ed. by B. Roizman). Plenum Press, New York and London, 319-366. 